Review

\title{
Fire's Effects on Grassland Restoration and Biodiversity Conservation
}

\author{
Hui Yan ${ }^{1,2}$ and Guixiang Liu ${ }^{1, *}$ \\ 1 Institute of Grassland Research of Chinese Academy of Agricultural Sciences, Hohhot 010010, China; \\ yanhuixixi@126.com \\ 2 Inner Mongolia Academy of Forestry Sciences, Hohhot 010010, China \\ * Correspondence: liuguixiang@caas.cn; Tel.: +86-158-4816-9829
}

\section{check for}

updates

Citation: Yan, H.; Liu, G. Fire's Effects on Grassland Restoration and Biodiversity Conservation.

Sustainability 2021, 13, 12016. https:/ / doi.org/10.3390/su132112016

Academic Editor: Alejandro Rescia

Received: 10 August 2021

Accepted: 18 October 2021

Published: 30 October 2021

Publisher's Note: MDPI stays neutral with regard to jurisdictional claims in published maps and institutional affiliations.

Copyright: (C) 2021 by the authors. Licensee MDPI, Basel, Switzerland. This article is an open access article distributed under the terms and conditions of the Creative Commons Attribution (CC BY) license (https:/ / creativecommons.org/licenses/by/ $4.0 /)$.

\begin{abstract}
Ecosystem succession and biodiversity change associated with grassland fires are crucial for the patterns and dynamics of ecosystem functioning and services. The reactions to fire by different grassland types vary diversely, and are determined by certain species assemblages and environments. However, there are still uncertainties concerning the role of fire in affecting grassland ecosystems and how the effects are sustained. By conducting a bibliometric analysis of related articles indexed in the Web of Science between 1984 and 2020, we firstly described the general trend of these articles over the recent decades (1984-2020). The major research progress in the effects of fire on grassland ecosystems was then systematically summarized based on three levels (individual level, community level, and ecosystem level) with eight topics. We concluded that strong persistence or resistance of adapted individuals facilitated community conversion to a novel environment, which temporally and spatially interacted with ecological factors. The novel habitats could maintain more frequent fires and change an ecosystem structure and functioning. Nonetheless, the transformation of ecosystem states will present more uncertainties on prospective succession trajectories, global carbon storage, and subsequent biodiversity conservation. This review is important to flourish biodiversity, as well as aid conservation policies and strategy making.
\end{abstract}

Keywords: grassland restoration; fire; ecosystem structure and functioning; biodiversity; ecosystem services

\section{Introduction}

Grasslands spread widely across the world, covering almost $40 \%$ of the world's surface, including the tropical and sub-tropical savannas in Africa, Australia and South America, the temperate prairies in North America, and the steppes in Eurasia [1]. With enhanced recognition of the importance of grassland conservation on an ecosystem structure and functioning, as well as biodiversity, more and more efforts have been made in grassland protection over the recent decades [1-3]. Specifically, the global grassland area has decreased by $40 \%$ since the era of industrialization [4], sounding the alarm on grassland restoration and conservation. Therefore, we need to further endeavor to figure out how grasslands react to human activities (e.g., fire, agriculture, urbanization, desertification, grazing, fragmentation, and biological invasion [4]), and what roles these disturbances have played in grassland ecosystems in terms of both short-term and long-term scales.

However, there are still some uncertainties regarding the responses of grassland ecosystems to disturbances $[5,6]$. Among all the factors, fire is considered to be a dominant disturbance affecting grassland distribution and dynamics [7]. About $80 \%$ of fires occur in grasslands globally [8]. Hence, it is urgent to describe and understand the effects of fire on grassland restoration and dynamics, as well as biodiversity conservation.

Fire could be distinguished into wildfire and prescribed fire, according to whether it is recognized as a promising management tool for grasslands. The causes of these two types of fire may both be related to humans. However, prescribed fires, applied by people, 
are meant to better manage grasslands and improve ecosystem functioning and services; they are implemented annually or at fixed rotations and are carefully designed to meet conservation goals [5]. Prescribed fires form a major part of North American grassland restoration efforts [5]. In addition, fire also varies among different levels, concerning burn area, severity, frequency, and season [9]. Understanding the effects of fire is an integral process involved in regional and global biogeochemical cycles, human activities, biodiversity dynamics, and vegetation patterns [3,10]. A systematic description of the influences of fire on biotic and abiotic components in an ecosystem cannot be isolated from specific fire patterns, biodiversity, and environmental heterogeneity [11]. Notably, due to the time lag of the reaction of biodiversity, the state and functioning of post-fire ecosystems change with the duration of recovery [6]. This means that the assessment of grassland restoration needs to integrate long-term grassland ecosystem monitoring with extensive field investigations, including traits, community biodiversity, ecosystem functioning, and evolutionary information.

For a given grassland, the effects of fire fall into the following three major levels: individual, community, and ecosystem [6,12]. At the individual level, changes in resistance traits and evolutionary adaptations are major reactions to fire [13]. If the changes in traits and the evolution of given individuals fail to guarantee survival or restoration, community-level changes will occur [14]; for example, fire could induce invasion by nonnative species [15], and promote the establishment and flourishing of other fire-adapted native species [16,17]. Ultimately, varied populations and communities lead to new succession trajectories [18] and changed biodiversity [19]. Lastly, the ecosystem structure and functioning would also transform substantially with the restoration processes after a fire [20]. Moreover, some scientists focus this topic on the aspect of paleoecology and endeavor to explain the long-term roles of fire in grassland ecosystems [2,21]. Hence, here, grassland restoration is defined not only as restoring post-wildfire grassland to its pre-fire state, with unchanged or undeclined biodiversity and ecosystem functioning, but also as managing degraded or wildfire-prone grasslands to restore them to a desirable state by carefully designed prescribed fires. Similarly, here, we define biodiversity conservation as the effects of wildfire on the species, genetic and ecosystem diversity, and as the targeted species maintained by prescribed fires.

Ecologists and conservationists have devoted considerable efforts to the identification of universal relationships between fire and grassland restoration and biodiversity conservation by models, field measurements, remote sensing monitoring, and fossil records. However, most studies focus on one or two aspects of the effects of wildfires or prescribed fires on biodiversity conservation and restoration. It is harder to understand the comprehensive influence of wildfires and prescribed fires on a range of aspects, from individual traits and evolution to whole-ecosystem functioning over the short and long term. Additionally, those areas where prescribed fires are applied are usually accompanied by frequent wildfire occurrence. Thus, we reviewed the effects of both wildfires and prescribed fires on grassland restoration and biodiversity conservation, aiming to (i) describe the ecosystem recovery from wildfires and prescribed fires systematically, based on three levels with eight topics. The first level was the individual level, with topics on species traits and evolution. The second level was the community level, with three topics on community succession, invasion, and biodiversity dynamics. Lastly, the ecosystem level involved in carbon and nitrogen cycles, resilience, as well as paleoecology. We also sought to (ii) raise public awareness of how grassland restoration responds to wildfires and prescribed fires, and advance our ability to restore grassland community structure and functioning by prescribed fires and post-wildfire; (iii) achieve the goal of biodiversity conservation by integrating various research methods, both temporally and spatially.

\section{Materials and Methods}

To detect the number of publications in each year, countries with most publications, journals with most publications, and the most frequent keywords, we used Web of Science 
Core Collection for Advanced Search and typed "TS = (prairie fire* OR grassland fire* OR steppe fire* OR rangeland fire) AND TS $=($ recovery* OR regeneration* OR restoration)" to obtain related papers from 1984 to April 2020.

To describe the effects of fire on grassland restoration comprehensively, we sorted all the searched publications by total cited times and read the top 200 papers to review the fire's effects on grasslands. To better summarize the current hot topics related to the effects of fire on grasslands, we also searched papers on prestigious journals, i.e., Nature, Science, Proceedings of the National Academy of Sciences of the United States of America and Nature communications, with the topics of fire and ecology on Web of Science Core Collection. We then identified the knowledge gaps that should be filled to improve our understanding of the effects of fire on grassland restoration and biodiversity conservation.

All these searched papers were exported in the format of BibTeX, and were analyzed in R using "Bibliometrics" package.

\section{Results}

Using those keywords, the search returned 1530 papers, with 1363 articles, 58 reviews, 91 proceedings papers, 10 early access papers, seven editorial materials, and one correction. A significant and positive linear relationship could be found between the number of publications in each year and the years $\left(R^{2}=0.95\right.$; Figure $\left.1 \mathrm{~A}\right)$, implying gradually increasing attention to the effect of fire on grasslands, as well as the subsequent grassland restoration and biodiversity conservation. The USA had the most publications (892 papers) on this topic, in terms of both the single country publications and multiple country publications, followed by Australia (117 papers), Argentina (54 papers), Canada (45 papers), Spain, South Africa, Brazil, China, the United Kingdom, and Mexico (Figure 1B). Additionally, about $7 \%$ of the papers (109 papers) were published in Rangeland Ecology Management, followed by Restoration Ecology (89 papers), Forest Ecology and Management (67 papers), Natural Areas Journal (41 papers), Journal of Vegetation Science, Ecological Applications, International Journal of Wildland Fire, Journal of Arid Environments, Ecosphere, and Applied Vegetation Science (Figure 1C).

To assess if the hotspots over the past decade are different from earlier studies, we divided the 1530 papers into two periods, which were pro-25-year period (1984-2009) and the last decade period (2010-2020). By ordering the frequency of keywords shown in these studies, we found that the frequency of savanna, management, prairie restoration, vegetation dynamics, diversity, woodland, and fire history decreased in the last decade. Comparatively, the novel top 20 keywords in the last decade were wildfire, rangeland, climate change, conservation, drought, and remote sensing. This indicated that the research focus on grasslands associated with fire was changing (Figure 2).

Only 126 of the 200 most cited papers were related to grassland fires. Similarly, when the papers in Nature, Science, Proceedings of the National Academy of Sciences of the United States of America, and Nature Communications were searched, with the topics of grassland fire recovery by the Web of Science Core Collection, although 46 papers were returned, only 19 of them focused on grassland fires. 


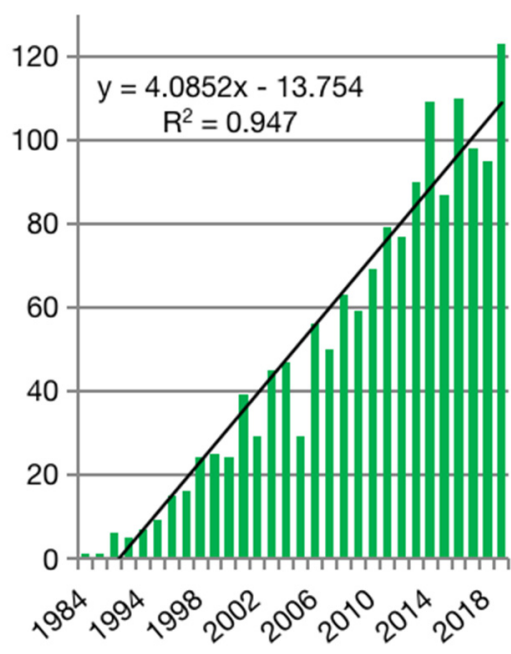

A

\section{C \\ Rangeland Ecology Management Restoration Ecology \\ Forest Ecology and Management Natural Areas Journal Journal of Vegetation Science Ecological Applications International Journal of Wildland Fire Journal of Arid Environments Ecosphere Applied Vegetation Science Plant Ecology Australian Journal of Botany Journal of Applied Ecology Biological Conservation Austral Ecology Fire Ecology American Midland Naturalist Environmental Management Northwest Science}

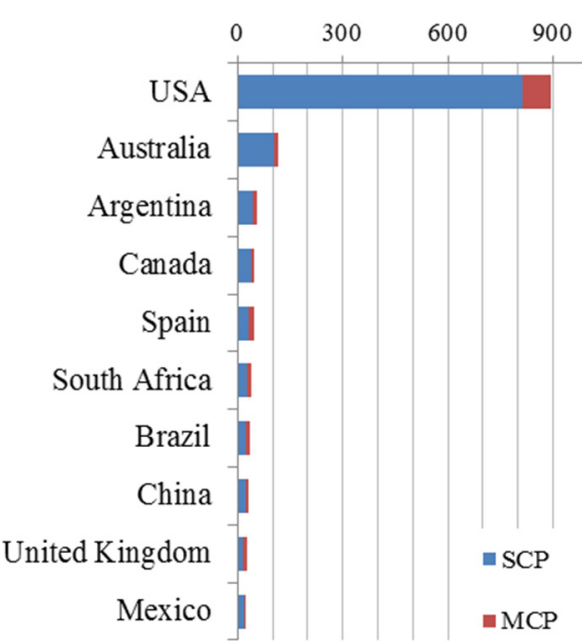

B

$0 \quad 40 \quad 80 \quad 120$

Figure 1. The number of articles published annually (A), 10 countries with most publications (B), and 20 journals with most papers (C) on grassland recovery from fires based on Web of Science Core Collection during 1984-2020. Because we only have four months of results in 2020, A shows the annual publication numbers during 1984-2019, and the bars represent the number of published papers on the topic in each year. The line is the regression line of publication numbers in each year against years. The bars in B represent the number of published papers in a country; blue bars indicate the single country publications (SCP) and red bars show the multiple country publications (MCP). The bars in $\mathrm{C}$ represent the number of published papers in a journal. 

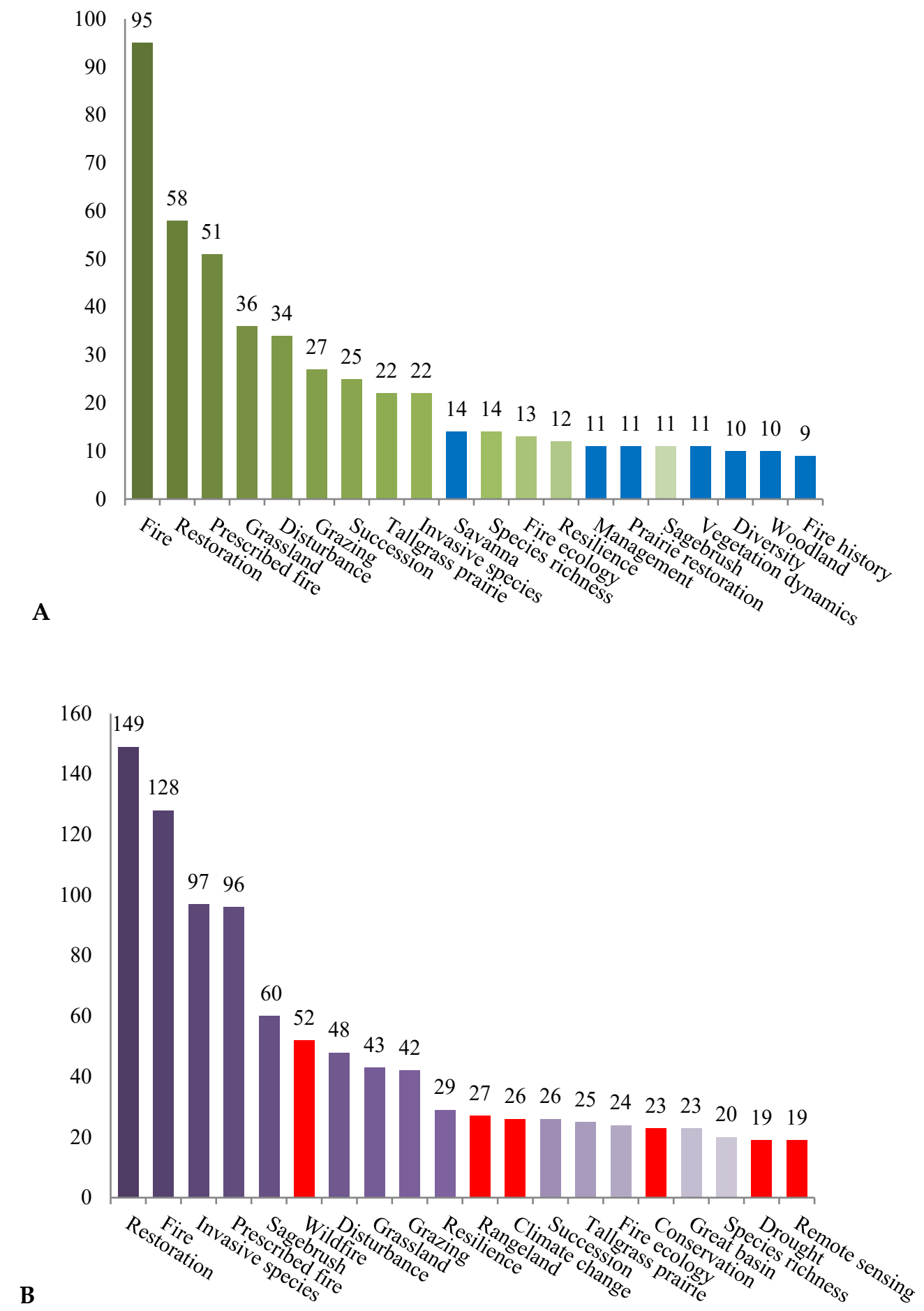

Figure 2. Top 20 keywords shown in papers on grassland recovery from fires based on Web of Science Core Collection. The bars represent the frequency of a keyword. (A,B) are the top 20 keywords during pro-25-year (1984-2009) and last decade (2010-2020), respectively. Seven keywords with blue bars in A indicate less frequency in last decade. Additionally, six keywords with red bars in B are novel keywords in last decade.

\section{Major Progresses}

In order to describe the influence of fires on grasslands in detail, based on the 200 most cited papers and 46 papers in prestigious journals, we firstly carefully read all these papers and tried to summarize the main findings or key questions of each paper. Based on this, we then categorized the fire's effects into three levels, i.e., the individual level, the community level, and the ecosystem level, which were further divided into eight topics 
(species trait, evolution; community succession, invasion, biodiversity; carbon and nitrogen cycles, resilience, paleoecology; Figure 3).

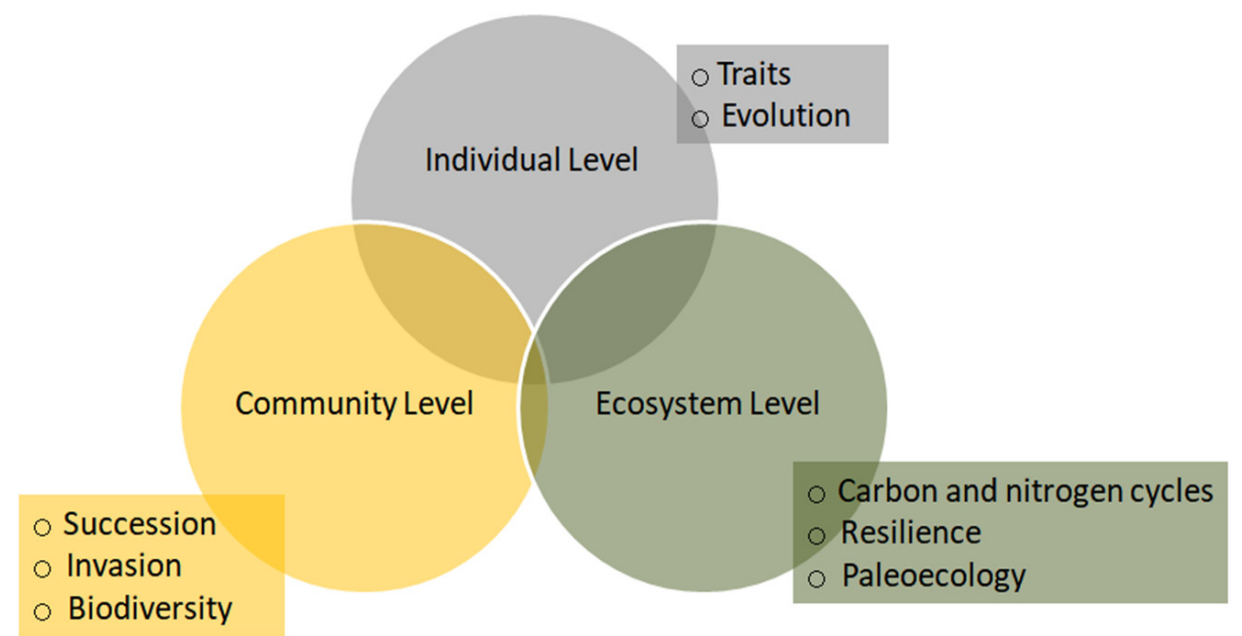

Figure 3. Major progress is summarized into three levels and eight topics.

\subsection{Individual-Level Effects}

\subsubsection{Species Traits}

The recovery processes of plant communities post-fire are strongly related to species traits, e.g., photosynthetic pathways, location of buds, and seed germination [22,23]. Meanwhile, the moisture condition, soil type, and grazing intensity interact to affect the vegetation recovery [24]. Specifically, with a high photosynthesis rate and efficient energy storage from leaves to roots, C4 plants are widely considered to be the dominant species in open and warm habitats, as well as in the novel environment induced by controlled burning [22]. Herbaceous functional group diversity is promoted by eliminating C 3 perennial grass dominance and flourishing C4 perennial grasses and C3 forbs through fire treatment [25].

Notably, the location of buds is one of the major determinants for the high abundance of C4 plants in post-fire treatment, indicating that rhizome plants could have higher resprouting ability compared to those plants with stolons and crowns [23]. Moreover, the effect of resprouting ability on fire severity is strongly associated with the depth of buried buds belowground. It is proven that the deeper that buds are buried, the more resilient they are to the high-severity soil heating released by fires [26]. As a result, plants with a large bud bank and high photosynthesis rate could recover more quickly and survive in more complicated environments driven by fire [27]. The main effects of fire on vegetative reproduction could be ramet natality, but not mortality [28].

Many studies have illustrated the relationships between fire patterns and reproduction ways, including being re-sprouted by a bud bank and re-established by a seed bank [29]. The effects of fire on seed germination could be categorized into three parts, i.e., fire's direct effects, heterogeneous environment created by fire, and seed traits. According to prescribed fire management, the direct effects of fires, such as the temperature and heat duration, are negatively correlated to seed germination [30]. Additionally, the heterogeneous environment created by wildfires, such as the open canopy, is positively correlated with seed germination and the establishment of perennial forbs [31]. Lastly, seed traits also play important roles in seed germination and resistance; for example, large seeds are more likely to survive from prescribed fires, and are subsequently more likely to germinate [30]. Consequently, plant traits, including physiological, morphological, phenological, and reproductive features, could well reflect their ability to respond and adapt to the post-wildfire and prescribed fire environment [32]. 


\subsubsection{Evolution}

Surviving and restoring from either wildfires or prescribed fires depends on the adaption of grasses, especially the reproduction characteristics and the heritability of adapted traits. Given the divergent evolutionary histories of each biome and various traits among species, plants may respond to a fire differently [13]. With increased pressure, particularly in fire-prone natural or human-managed grasslands, species have adapted to the habitat by their different evolutionary histories, not by the variation in the expression of traits $[33,34]$.

Notably, it is proven by fossil records that evolutionary response is a vital strategy of grasses' responses to fire [33]. In addition, heat, smoke, or fluctuated temperature by fire treatment is the prerequisite for some seeds to germinate [35]. Additionally, flowering is only triggered by fire in some geophytic species [36], indicating that flowering associated with fire may be an important component of evolution history in natural ecosystems. In which reproductive way the ancestor responds to fire is still controversial, given the current evidence [13,37]; this is because both resprouting and seed germination are direct or indirect adaptations to wildfires and prescribed fires [38,39]. Moreover, some detailed and heritable plant traits (e.g., dense bark, more serotinous fruit, hard seed) and some mammal behaviors (e.g., burrowing and evasion) are the evidence of fire adaptation in natural ecosystems $[13,40]$. Specifically, in fire-free natural habitats, frequently, human-made fires would prefer seeds with heritable traits, which are more pubescent, less rounded, and have thicker pericarps [41].

Hence, fire plays a significant role in driving grasses' evolutionary changes, either by wildfires or prescribed fires. Specifically, with the increased risk of wildfires caused by climate change and human activities, natural selection on fire-adaptive traits could probably be accelerated, which would change the ecosystem diversity and functioning. Additionally, as an effective management tool for grassland ecosystems, prescribed fires can provide outstanding opportunities for vegetation, to adapt stronger fire selective pressures and to show more favorable traits related to fires.

\subsection{Community-Level Effects}

\subsubsection{Community Succession}

Fire occurs in different seasons, diverse frequencies, and various severities, resulting in divergent species coverage, richness, flowering, and distinctive communities $[14,42,43]$. Specifically, summer fire treatment could impede late-flowering C4 grass dominance, and promote the persistence and flourishing of early flowering species [42]. Because of the strong effects of fire on community succession, managers adopt prescribed fires to improve community composition and enhance grassland productivity [5]. The evolved distinct 'maquis' vegetation of New Caledonia is ascribed to not only the soil chemical factor, but also the periodic fires and varying degrees of drought [44].

Notably, a sagebrush recovery study finds that the average time for the full recovery of sagebrush post-wildfire is 32 years, and there are no significant relationships between vegetation recovery and annual precipitation or soil texture, indicating the crucial role of fire in shaping vegetation recovery [45]. Particularly, vegetation is strongly affected by the recent fire, and the succession stages are highly consistent with the post-fire duration [18]. Moreover, the post-fire environment could facilitate grasses with a high growth rate to compete for the novel space and light radiation [27]. Given the efficient accumulation of biomass and fast occupation of novel niches, competition exclusion is ultimately accomplished by shading rather than repeated fires [16]. Consequently, as a useful and promising management tool, fire could be applied to shape community assemblages [44]; for example, the past prescribed fires in the Australia savanna, dominated by eucalypts, could effectively limit non-eucalypt trees' maturity, and could lead to changed community trajectories [46]. Additionally, by combining prescribed fires with grazing and grass seed sowing, grassland restoration achieved desirable effects, i.e., more heterogeneous habitats [1], efficient biodiversity conservation [44], improved community composition [47], and a declined risk 
of uncontrolled wildfire occurrence [48], either for prairies and annual grasses in North America and the Mediterranean [49,50], or for savannas in Australia and Africa [47].

Numerous studies have reported that woodlands have encroached on grasslands extensively in Australia, North America, and South Africa. Thus, how to halt woodland expansion is a major concern regarding restoration plans to maintain grasslands [45,51]. By combining cutting woody plants with prescribed fires fueled by pre-cutting branches, woody plant-dominant grasslands have successfully been restored to fully herbaceous communities with native perennial grasses by the third year after the prescribed fire in Idaho [52].

Conclusively, to meet long-term grassland restoration and biodiversity conservation goals, the application of prescribed fires may be necessary. Interestingly, unlike the savannas in Africa and South America, the abundance of trees in the Northern Australia savanna is largely constrained by water, but less affected by fires [53]. This implies that not all successful prescribed fire cases are suitable for other regions, and not all prescribed fires related grassland restoration measures are adoptable for other grassland ecosystems. The major point of attention is the site-specific climate and community composition. Thus, more experiments based on specific habitats are needed to find the exact effects of fire on community assemblage, to choose optimal grassland restoration measures to eliminate or reduce the side effects of uncontrolled wildfires, and to improve grassland management.

\subsubsection{Invasion}

The burning of grasslands releases a considerable amount of nutrients into the environment, which facilitates nitrophiles to regenerate and accelerates fire recurrence to some extent [6]. Due to the strong limits of nitrogen for grasses, an enhanced nitrogen supply would promote the distribution of exotic grasses [54]. Exotic grass species could boost fire recurrence, enhance fire size, and decrease the number of native species and net primary productivity [54].

Wildfires are considered to be a critical threat, by promoting exotic species invasions and transforming sagebrush communities to nonnative annual grasslands [55]. Notably, even without the reoccurrence of fires over 37 years, native species still weakly recover from the exotic-dominant communities compared to unburned plots [56]. During the process, community trajectories gradually change over time. Additionally, nutrient limitation may have resulted from the long-term depletion of nitrogen by exotic grasses, and other better adapted species will then dominate the new habitat [51]. Hence, recovering the pre-wildfire native state from invasive vegetation is extremely difficult due to frequently recurrent wildfires and environmental changes [15]. It is illuminated that grassland restoration should pay more attention to the existence of native perennial plants [57]. The less native the perennial species in the novel environment, the harder it is to restore native perennial vegetation [57].

Similarly, in the early stage of prescribed fires, frequent burnings in the tropics could promote exotic annual grass invasion in the big sagebrush (Artemisia tridentate Nutt.) ecosystem [52], while low fire frequency causes conifer encroachment in the big sagebrush ecosystem [55]. The success of exotic species invasion in the prescribed fire grassland ecosystems widely depends on the fire regimes and native species abundance. Notably, prescribed fires have been adopted by managers to exclude invasive exotic species and to prevent re-invasion by them in prairies and savannas; for example, in North American prairies and Mediterranean annual grasslands, repeated prescribed fires are applied in the dormant season or growing season to prevent invasive species from regenerating. This project decreases the risk of re-invasion [49]. Moreover, summer burning in the mid-west USA may be effective for controlling invasive species [50]. Besides prairies and annual grasslands, savannas in Australia, Africa, and Brazil were also managed by fire to control invasion and maintain a balanced woody-to-grass ratio, mainly by controlling fire timing, distribution, size, and intensity [47]. 


\subsubsection{Biodiversity}

Grasslands are considered to be the most diverse ecosystem globally, with even higher plant diversity than tropical rainforests at a smaller spatial grain (e.g., 89 species on $1 \mathrm{~m}^{2}$ ) [58]. Meanwhile, there are tremendous differences in biodiversity among different grassland types [59]. Due to severe challenges to global diversity by anthropogenic activities, grasslands are unavoidably undergoing degradation and biodiversity loss [60]. Alarmingly, grassland wildfires accelerate diversity loss by decreasing the abundance of multiple native species and enhancing the proportion of exotic species [19]. Besides the concerns on plant community transitions caused by fire, biological soil crust, birds, invertebrates, reptiles, and mammals respond to fire strongly as well [61-65].

Biological soil crust is considered to be crucial for improving soil structure and functioning, as well as maintaining the soil microbial community [61]. It has been proven that mosses could facilitate ecosystem functional recovery from wildfires [66]. However, strong reactions of biological soil crust to fire have been documented, according to fire experiments [67]. The evaluation of the understory recovery ability in the Great Basin of North America suggests that the cover and density of biological soil crust declines in fire treatments compared with control ones [67]. Another study also states that the abundance of lichen and moss is lower in burned areas than in unburned sites [68]. Additionally, the resistance of tall moss to fire is better than lichen [69]. Other factors, such as precipitation, reproduction strategy, and survival from other disturbances, are all related to crust recovery [70].

In regards to the faunas' reactions to fire, the interactive effects of multiple disturbances were strong, and the potential responses to different disturbances were species-specific [71]. There is much evidence on the faunas' (including invertebrate, seeding herbivore, insect, reptile, and bird) responses to fire, and most of their responses are associated with vegetation conditions [12]. Passive relationships between biodiversity and fire occurrence are found in the study of invertebrates, including the lower activity of invertebrates and herbivores in burned plots [63]. Moreover, the duration of the exacerbation depends on the levels of fire size and severity, as well as the environmental conditions. For insects, they needed about two years to restore their community size after the prescribed fire on small prairie sites of Wisconsin and Indiana [72]. However, there are no significant relationships between reptile richness and fire conditions (e.g., numbers or severity), and the main cause of reptile richness variation is the vegetation conditions following a wildfire [64]. Notably, both bison (Bison bison) and cattle (Bostaurus) preferred recently prescribed burned areas in tallgrass prairie [65].

Variations in vegetation structure and composition could affect bird community dynamics as well [62]. Enhanced bird diversity and improved bird community structure could be found in plant patches with different states of vegetation regrowth after fires [73]. Changes in bird community structure are caused by significant decreases in some species, which cannot adapt to the novel environment, and increases in other species that have stronger competition ability in the fire treatment [74]. Particularly, savanna restoration related to prescribed fire frequency is accompanied with a reduction in insectivorous birds, which fed on the higher canopy area, but an increase in omnivorous birds, which fed on the ground or lower canopy area [75]. According to the observation, changes in fire frequency could increase the abundance and richness of birds favored in open areas [76]. Specifically, it is clearly found that bird community recovery from natural fires extensively benefits from vegetation regrowth [55]. Additionally, a bird community could recovery from a prescribed fire in two years in Southern Brazilian highland grasslands [77]. Additionally, a case study covering a gradient of fire frequency treatments finds that fire could change small mammal richness and abundance [74]. Changing small mammal communities have resulted in shifts in the ecosystem structure and functioning by food chain [78].

Consequently, high-severity wildfires may affect biodiversity catastrophically, resulting in declined biodiversity and long periods of restoration, or sometimes even biodiversity that is hard to restore $[63,67]$. However, it is not all about the side effects of fire on biodiver- 
sity, and usually a lower-severity fire could promote biodiversity by creating heterogeneous habitats. Whether fire could improve biodiversity depends on its size, season, frequency, and intensity for savannas in Southern Africa [79] and Australia [48]. Besides, compared with the direct effects of heat on biodiversity, the indirect effects of fire are more crucial [5]. Hence, we can conclude that all the species in grasslands should be considered integrally, and are restricted by food chain and environmental changes. Applicable management tools should combine fire conditions and local environmental attributes together in order to conserve favorable species and increase landscape-level heterogeneity.

\subsection{Ecosystem-Level Effects}

\subsubsection{Carbon and Nitrogen Cycles}

As an essential part of environmental changes, variations in carbon and nitrogen cycles are crucial to depict the relationships between fire and grassland restoration and biodiversity conservation [10]. By combustion, more carbon is released into the ecosystem. Moreover, this will accelerate the cycle of primary production and respiration [80]. However, the implementation of numerous fire management plans generates carbon credits in the Northern Australian savanna [53]. Similarly, by prescribed fires in the early dry season of the African savanna, it is possible to reduce more greenhouse gas emissions than wildfires [47]. Thus, the effects of fire on carbon and nitrogen emission depend on the monitoring and application of fire over larger spatial and temporal scales.

Additionally, black carbon aerosols, emitted by burning, have intensified light absorption and led to a warming condition, which may affect vegetation restoration [3]. Moreover, in a semi-arid hummock grassland ecosystem, increases in $\mathrm{pH}$, electrical conductivity, and nutrient availability are the immediate influences of wildfires on soil properties [81].

Generally, the more severe the fire, the more soil mineral nitrogen released by wildfires and prescribed fires [82]. Soil surface temperature is a priority in driving ammonia release in postfire experiments, while the type and amount of burnt biomass limits the increase in nitrate [83]. As a result, due to the deposition of ash with more available nitrogen and phosphorus by simulated burning, the nutrient availability on the soil surface increases by 12-fold compared to non-fire sites [84]. Moreover, this state will be naturally maintained on the soil surface for many years [85].

Controversially, others argued that fire could drive a long-term decline in soil carbon and nitrogen content, and facilitate low-nitrogen plants to flourish, resulting in a gradually changing vegetation composition [86,87]. Specifically, exotic grasses promoted by fire could accelerate nitrogen cycling rates and increase the growth of themselves in Hawaii [88]. A meta-analysis focuses on the effects of fire on soil nitrogen amount, concentration, ammonium, and nitrate, and suggests that the conditions of an ecosystem's nitrogen depends on vegetation type, fire pattern, fuel type, fire duration, and soil sampling depth [89]. Moreover, due to nitrogen restriction on plant growth and a changing soil carbon pool, various fire frequencies could alter an ecosystem's carbon sink capacity [87]. Additionally, the ratios of fungi to bacteria and of microbial carbon to total organic carbon are effective indices for soil recovery from the long-term perspective [81].

\subsubsection{Resilience}

Ecosystem resilience related to wildfires means the capacity of the ecosystem to restore or recover to the pre-fire condition, with a similar structure and functioning [90]. Ecosystem resilience to various disturbances largely depends on the dominant species' reaction [91]. State and transition models are widely used to predict vegetation community and environment dynamics [92]. Due to the diverse ways of plant reproduction and survival, as well as various fire patterns, vegetation changes differently and forms alternative community states gradually [3]. Notably, the faster post-wildfire recovery in South Africa is associated with higher soil fertility, minimum winter temperature, and mean summer precipitation [93]. 
The resilience of a grassland ecosystem to fire is also greatly related to the fire histories and the contexts of vegetation organization, especially for prescribed fires aiming to manage and improve grassland forage and ecosystem functioning; for example, a study that lasted over 20 years, in a tallgrass prairie in Eastern Kansas, USA, about the effects of prescribed fires on grassland vegetation restoration, finds different restoration processes between two ecosystems with reverse fire histories, from infrequent fires to annual prescribed fires, and from annual prescribed fires to no fires. Moreover, it is more difficult to recover vegetation compositions from an annually burned ecosystem to an unburned state than those from infrequently burning to annually burning, which is called "hysteresis" [6]. This implies that the influence of prescribed fires on the ecosystem resilience is significant. Notably, it is also suggested that more attention should be paid to choosing fire as the grassland management tool because community composition, structure and functioning, and patchy habitat are site-specific. As a result, resilience benefits from high resource availability and more desired environmental factors for target species.

\subsubsection{Paleoecology}

Paleoecology provides a long-term insight into current grassland ecosystem research, including ecosystem structure and functioning, functional diversity, and the formation of shrub-grass ecotones [2]. Many palaeoecological records, including charcoal, fossil, pollen, seeds, and fruits, are used to analyze the effects of fire on an ecosystem structure and functioning $[8,12,87]$. Notably, a growing number of ecologists realized the importance of the palaeoecological implications, and recognized that fires were the predominant factor controlling the rise in grassy ecosystems during the Miocene [94,95].

For example, through palaeoecological records, it is found that the frequent occurrence of fires was promoted and sustained by grassland ecosystems themselves [96]. Moreover, fire plays a crucial role during the process of the dominance of C4 grasses in the MioPliocene [21]. Additionally, the overwhelming competition of grasses with fire, compared with trees, makes grasses widespread in the Holocene [97]. With increased $\mathrm{CO}_{2}$ concentration and an associated lower sapling recovery rate, grasses recovered rapidly after the fire. The slow tree recovery following the fire in the Late Tertiary might not be strongly related to the competition in photosynthetic pathways between $\mathrm{C} 3$ and $\mathrm{C} 4$, but more related to $\mathrm{CO}_{2}$ concentration [98]. Therefore, paleoecology could provide a new perspective for the assessment of the effects of fire, and, obviously, all these findings bring paleoecology under new scrutiny.

\section{Conclusions}

Fire plays a critical role in affecting a grassland ecosystem functioning and dynamics because almost $80 \%$ of global fires occurred in grasslands [8]. In order to better understand the relationships between wildfires, prescribed fires and floras, faunas, ecosystem functioning and dynamics, and to comprehensively assess the applications of fire management projects, our review synthesizes the important aspects of grassland conditions driven by wildfires and prescribed fires. These aspects include plant traits and evolution, community structure and composition, biodiversity, ecosystem functioning, and paleoecology. Prewildfire or pre-prescribed fire species could be substituted by more fire-adapted species with strong persistence or resistance to fires. During the process of community conversion, environmental conditions, such as nutrient cycling and soil storage, were altered as well. Conclusively, the assessment of whether this process is better or not for grassland ecosystem functioning and services largely depends on the aims of grassland restoration and biodiversity conservation.

Additionally, the effects of fire on a novel environment temporally and spatially interact with ecological factors. The transformation of ecosystem states will present more uncertainties on prospective succession trajectories, global carbon storage, and, subsequently, biodiversity conservation. Controlled wildfires and carefully applied prescribed fires may improve a grassland ecosystem functioning and services, while uncontrolled 
wildfires and misused prescribed fires could lead to catastrophic effects on grassland restoration and biodiversity conservation. It is also emphasized that more attention needs to be paid before prescribed fires can be applied. Thus, plenty of work still remains to be performed on the prediction of ecosystems dynamics and their responses to fires, both in specific habitats and at regional and global scales. Crucially, it is desirable to combine short-term observation experiments, long-term remote sensing analyses, and paleoecology together to describe the fire history effects on grassland restoration in detail, to flourish biodiversity, and to aid conservation policy and strategy making.

Author Contributions: Conceptualization, H.Y. and G.L.; methodology, H.Y.; formal analysis, H.Y.; investigation, H.Y.; writing—original draft preparation, H.Y. and G.L.; writing—review and editing, H.Y. and G.L.; visualization, H.Y.; supervision, G.L. All authors have read and agreed to the published version of the manuscript.

Funding: This work was funded by the Science and Technology Innovation Project "Grassland Nonbiological Disaster Prevention and Mitigation Team" of Chinese Academy of Agricultural Sciences (Grant No. CAAS-ASTIP-IGR2015-04), National Natural Science Foundation of China (41761101), and Natural Science Foundation of Inner Mongolia (2017MS0409).

Institutional Review Board Statement: Not applicable.

Informed Consent Statement: Not applicable.

Data Availability Statement: Not applicable.

Conflicts of Interest: The authors declare no conflict of interest.

\section{References}

1. Buisson, E.; Le Stradic, S.; Silveira, F.A.O.; Durigan, G.; Overbeck, G.E.; Fidelis, A.; Fernandes, G.W.; Bond, W.J.; Hermann, J.M.; Mahy, G.; et al. Resilience and restoration of tropical and subtropical grasslands, savannas, and grassy woodlands. Biol. Rev. 2019, 94, 590-609. [CrossRef] [PubMed]

2. Willis, K.J.; Birks, H.J.B. What is natural? The need for a long-term perspective in biodiversity conservation. Science 2006, 314, 1261-1265. [CrossRef]

3. Bowman, D.; Balch, J.K.; Artaxo, P.; Bond, W.J.; Carlson, J.M.; Cochrane, M.A.; D'Antonio, C.M.; DeFries, R.S.; Doyle, J.C.; Harrison, S.P.; et al. Fire in the Earth System. Science 2009, 324, 481-484. [CrossRef] [PubMed]

4. White, R.P.; Murray, S.; Rohweder, M. Pilot Analysis of Global Ecosystems: Grassland Ecosystems; World Resources Institute: Washington, DC, USA, 2000; Volume 4, p. 275.

5. Valko, O.; Torok, P.; Deak, B.; Tothmeresz, B. Review: Prospects and limitations of prescribed burning as a management tool in European grasslands. Basic Appl. Ecol. 2014, 15, 26-33. [CrossRef]

6. Collins, S.L.; Nippert, J.B.; Blair, J.M.; Briggs, J.M.; Blackmore, P.; Ratajczak, Z. Fire frequency, state change and hysteresis in tallgrass prairie. Ecol. Lett. 2021, 24, 646-647. [CrossRef] [PubMed]

7. Pennington, R.T.; Hughes, C.E. The remarkable congruence of New and old world savanna origins. New Phytol. 2014, $204,4-6$. [CrossRef] [PubMed]

8. Leys, B.A.; Marlon, J.R.; Umbanhowar, C.; Vanniere, B. Global fire history of grassland biomes. Ecol. Evol. 2018, 8, 8831-8852. [CrossRef] [PubMed]

9. Hannusch, H.J.; Rogers, W.E.; Lodge, A.G.; Starns, H.D.; Tolleson, D.R. Semi-arid savanna herbaceous production and diversity responses to interactive effects of drought, nitrogen deposition, and fire. J. Veg. Sci. 2020, 31, 255-265. [CrossRef]

10. Kelly, L.T.; Brotons, L. Using fire to promote biodiversity. Science 2017, 355, 1264-1265. [CrossRef]

11. Ellsworth, L.M.; Kauffman, J.B.; Reis, S.A.; Sapsis, D.; Moseley, K. Repeated fire altered succession and increased fire behavior in basin big sagebrush-native perennial grasslands. Ecosphere 2020, 11, e03124. [CrossRef]

12. Bahia, R.; Zalba, S. Changes in grassland bird communities and breeding success after a fire in the Argentinian Pampas. Biodivers. Conserv. 2019, 28, 3767-3786. [CrossRef]

13. Lamont, B.B.; He, T.H.; Yan, Z.G. Evolutionary history of fire-stimulated resprouting, flowering, seed release and germination. Biol. Rev. 2019, 94, 903-928. [CrossRef] [PubMed]

14. Ratajczak, Z.; Nippert, J.B.; Briggs, J.M.; Blair, J.M. Fire dynamics distinguish grasslands, shrublands and woodlands as alternative attractors in the Central Great Plains of North America. J. Ecol. 2014, 102, 1374-1385. [CrossRef]

15. Ratajczak, Z.; D’Odorico, P.; Nippert, J.B.; Collins, S.L.; Brunsell, N.A.; Ravi, S. Changes in spatial variance during a grassland to shrubland state transition. J. Ecol. 2017, 105, 750-760. [CrossRef]

16. Rossiter, N.A.; Setterfield, S.A.; Douglas, M.M.; Hutley, L.B. Testing the grass-fire cycle: Alien grass invasion in the tropical savannas of northern Australia. Divers. Distrib. 2003, 9, 169-176. [CrossRef] 
17. Chambers, J.C.; Bradley, B.A.; Brown, C.S.; D’Antonio, C.; Germino, M.J.; Grace, J.B.; Hardegree, S.P.; Miller, R.F.; Pyke, D.A. Resilience to Stress and Disturbance, and Resistance to Bromus tectorum L. Invasion in Cold Desert Shrublands of Western North America. Ecosystems 2014, 17, 360-375. [CrossRef]

18. Mouillot, F.; Ratte, J.P.; Joffre, R.; Moreno, J.M.; Rambal, S. Some determinants of the spatio-temporal fire cycle in a Mediterranean landscape (Corsica, France). Landsc. Ecol. 2003, 18, 665-674. [CrossRef]

19. Koerner, S.E.; Burkepile, D.E.; Fynn, R.W.; Burns, C.E.; Eby, S.; Govender, N.; Hagenah, N.; Matchett, K.J.; Thompson, D.I.; Wilcox, K.R. Plant community response to loss of large herbivores differs between North American and South African savanna grasslands. Ecology 2014, 95, 808-816. [CrossRef]

20. Zirbel, C.R.; Bassett, T.; Grman, E.; Brudvig, L.A. Plant functional traits and environmental conditions shape community assembly and ecosystem functioning during restoration. J. Appl. Ecol. 2017, 54, 1070-1079. [CrossRef]

21. Karp, A.T.; Behrensmeyer, A.K.; Freeman, K.H. Grassland fire ecology has roots in the late Miocene. Proc. Natl. Acad. Sci. USA 2018, 115, 12130-12135. [CrossRef] [PubMed]

22. Moore, N.A.; Camac, J.S.; Morgan, J.W. Effects of drought and fire on resprouting capacity of 52 temperate Australian perennial native grasses. New Phytol. 2019, 221, 1424-1433. [CrossRef]

23. Pausas, J.G.; Paula, S. Grasses and fire: The importance of hiding buds. New Phytol. 2020, 226, 957-959. [CrossRef]

24. Villarreal, M.L.; Norman, L.M.; Buckley, S.; Wallace, C.S.; Coe, M.A. Multi-index time series monitoring of drought and fire effects on desert grasslands. Remote Sens. Environ. 2016, 183, 186-197. [CrossRef]

25. Ansley, R.J.; Castellano, M.J. Strategies for savanna restoration in the southern Great Plains: Effects of fire and herbicides. Restor. Ecol. 2006, 14, 420-428. [CrossRef]

26. Wright, B.R.; Clarke, P.J. Resprouting responses of Acacia shrubs in the Western Desert of Australia-Fire severity, interval and season influence survival. Int. J. Wildland Fire 2007, 16, 317-323. [CrossRef]

27. Archibald, S.; Hempson, G.P.; Lehmann, C. A unified framework for plant life-history strategies shaped by fire and herbivory. New Phytol. 2019, 224, 1490-1503. [CrossRef]

28. Benson, E.J.; Hartnett, D.C. The role of seed and vegetative reproduction in plant recruitment and demography in tallgrass prairie. Plant Ecol. 2006, 187, 163-177. [CrossRef]

29. Lamont, B.B.; Enright, N.J.; He, T. Fitness and evolution of resprouters in relation to fire. Plant Ecol. 2011, $212,1945-1957$. [CrossRef]

30. Gashaw, M.; Michelsen, A. Influence of heat shock on seed germination of plants from regularly burnt savanna woodlands and grasslands in Ethiopia. Plant Ecol. 2002, 159, 83-93. [CrossRef]

31. Morgan, J. Importance of canopy gaps for recruitment of some forbs in Themeda triandra-dominated grasslands in south-eastern Australia. Aust. J. Bot. 1998, 46, 609-627. [CrossRef]

32. Grigulis, K.; Lavorel, S.; Krainer, U.; Legay, N.; Baxendale, C.; Dumont, M.; Kastl, E.; Arnoldi, C.; Bardgett, R.D.; Poly, F. Relative contributions of plant traits and soil microbial properties to mountain grassland ecosystem services. J. Ecol. 2013, 101, 47-57. [CrossRef]

33. Lamont, B.B.; He, T. Fire-proneness as a prerequisite for the evolution of fire-adapted traits. Trends Plant Sci. 2017, 22, 278-288. [CrossRef] [PubMed]

34. Vesk, P.A.; Westoby, M. Sprouting ability across diverse disturbances and vegetation types worldwide. J. Ecol. 2004, 92, 310-320. [CrossRef]

35. Burrows, G.E.; Alden, R.; Robinson, W.A. The lens in focus-lens structure in seeds of 51 Australian Acacia species and its implications for imbibition and germination. Aust. J. Bot. 2018, 66, 398-413. [CrossRef]

36. Lamont, B.B.; Downes, K.S. Fire-stimulated flowering among resprouters and geophytes in Australia and South Africa. Plant Ecol. 2011, 212, 2111-2125. [CrossRef]

37. Lawes, M.J.; Keith, D.A.; Bradstock, R.A. Advances in understanding the influence of fire on the ecology and evolution of plants: A tribute to Peter, J. Clarke. Plant Ecol. 2016, 217, 597-605. [CrossRef]

38. López-Villalta, J.S. Trait-driven vs. syndrome-driven diversification in the Mediterranean woody flora. Ecol. Mediterr. 2014, 40, 27-33. [CrossRef]

39. El-ahmir, S.M.; Lim, S.L.; Lamont, B.B.; He, T. Seed size, fecundity and postfire regeneration strategy are interdependent in Hakea. PLoS ONE. 2015, 10, e0129027.

40. Causley, C.L.; Fowler, W.M.; Lamont, B.B.; He, T. Fitness benefits of serotiny in fire-and drought-prone environments. Plant Ecol. 2016, 217, 773-779. [CrossRef]

41. Gomez-Gonzalez, S.; Torres-Diaz, C.; Bustos-Schindler, C.; Gianoli, E. Anthropogenic fire drives the evolution of seed traits. Proc. Natl. Acad. Sci. USA 2011, 108, 18743-18747. [CrossRef]

42. Howe, H.F. Succession and fire season in experimental prairie plantings. Ecology 1995, 76, 1917-1925. [CrossRef]

43. He, T.; Lamont, B.B.; Pausas, J.G. Fire as a key driver of Earth's biodiversity. Biol. Rev. 2019, 94, 1983-2010. [CrossRef] [PubMed]

44. Proctor, J. Vegetation and soil and plant chemistry on ultramafic rocks in the tropical Far East. Perspect. Plant Ecol. Evol. Syst. 2003, 6, 105-124. [CrossRef]

45. Lesica, P.; Cooper, S.V.; Kudray, G. Recovery of big sagebrush following fire in southwest Montana. Rangel. Ecol. Manag. 2007, 60, 261-269. [CrossRef] 
46. Woinarski, J.C.Z.; Risler, J.; Kean, L. Response of vegetation and vertebrate fauna to 23 years of fire exclusion in a tropical Eucalyptus open forest, Northern Territory, Australia. Austral. Ecol. 2004, 29, 156-176. [CrossRef]

47. Nieman, W.A.; van Wilgen, B.W.; Leslie, A.J. A review of fire management practices in African savanna-protected areas. Koedoe 2021, 63, 1-13. [CrossRef]

48. Prichard, S.J.; Stevens-Rumann, C.S.; Hessburg, P.F. Tamm review: Shifting global fire regimes: Lessons from reburns and research needs. For. Ecol. Manag. 2017, 396, 217-233. [CrossRef]

49. Pyke, D.A.; Brooks, M.L.; D'Antonio, C. Fire as a restoration tool: A decision framework for predicting the control or enhancement of plants using fire. Restor. Ecol. 2010, 18, 274-284. [CrossRef]

50. Emery, S.M.; Gross, K.L. Effects of timing of prescribed fire on the demography of an invasive plant, spotted knapweed Centaurea maculosa. J. Appl. Ecol. 2005, 42, 60-69. [CrossRef]

51. Chambers, J.C.; Miller, R.F.; Board, D.I.; Pyke, D.A.; Roundy, B.A.; Grace, J.B.; Schupp, E.W.; Tausch, R.J. Resilience and Resistance of Sagebrush Ecosystems: Implications for State and Transition Models and Management Treatments. Rangel. Ecol. Manag. 2014, 67, 440-454. [CrossRef]

52. Bates, J.D.; Davies, K.W.; Sharp, R.N. Shrub-Steppe Early Succession Following Juniper Cutting and Prescribed Fire. Environ. Manage. 2011, 47, 468-481. [CrossRef]

53. Drewa, P.B.; Platt, W.J.; Moser, E.B. Fire effects on resprouting of shrubs in headwaters of southeastern longleaf pine savannas. Ecology 2002, 83, 755-767. [CrossRef]

54. Mack, M.C.; D'Antonio, C.M.; Ley, R.E. Alteration of ecosystem nitrogen dynamics by exotic plants: A case study of C4 grasses in Hawaii. Ecol. Appl. 2001, 11, 1323-1335.

55. Davies, K.W.; Boyd, C.S.; Beck, J.L.; Bates, J.D.; Svejcar, T.J.; Gregg, M.A. Saving the sagebrush sea: An ecosystem conservation plan for big sagebrush plant communities. Biol. Conserv. 2011, 144, 2573-2584. [CrossRef]

56. D'Antonio, C.M.; Hughes, R.F.; Tunison, J.T. Long-term impacts of invasive grasses and subsequent fire in seasonally dry Hawaiian woodlands. Ecol. Appl. 2011, 21, 1617-1628. [CrossRef]

57. Davies, K.W.; Sheley, R.L. Promoting native vegetation and diversity in exotic annual grass infestations. Restor. Ecol. 2011, 19, 159-165. [CrossRef]

58. Wilson, J.B.; Peet, R.K.; Dengler, J.; Pärtel, M. Plant species richness: The world records. J. Veg. Sci. 2012, 23, 796-802. [CrossRef]

59. Dengler, J.; Janišová, M.; Török, P.; Wellstein, C. Biodiversity of Palaearctic grasslands: A synthesis. Agric. Ecosyst. Environ. 2014, 182, 1-14. [CrossRef]

60. Horváth, Z.; Ptacnik, R.; Vad, C.F.; Chase, J.M. Habitat loss over six decades accelerates regional and local biodiversity loss via changing landscape connectance. Ecol. Lett. 2019, 22, 1019-1027. [CrossRef] [PubMed]

61. Yang, X.; Xu, M.; Zhao, Y.; Gao, L.; Wang, S. Moss-dominated biological soil crusts improve stability of soil organic carbon on the Loess Plateau, China. Plant Soil Environ. 2019, 65, 104-109. [CrossRef]

62. Casas, G.; Darski, B.; Ferreira, P.M.; Kindel, A.; Müller, S.C. Habitat structure influences the diversity, richness and composition of bird assemblages in successional Atlantic rain forests. Trop. Conserv. Sci. 2016, 9, 503-524. [CrossRef]

63. Hanley, M.E.; Lamont, B.B. Herbivory, serotiny and seedling defence in Western Australian Proteaceae. Oecologia 2001, 126, 409-417. [CrossRef] [PubMed]

64. Lindenmayer, D.B.; Wood, J.T.; MacGregor, C.; Michael, D.R.; Cunningham, R.B.; Crane, M.; Montague-Drake, R.; Brown, D.; Muntz, R.; Driscoll, D.A. How predictable are reptile responses to wildfire? Oikos 2008, 117, 1086-1097. [CrossRef]

65. Allred, B.W.; Fuhlendorf, S.D.; Hamilton, R.G. The role of herbivores in Great Plains conservation: Comparative ecology of bison and cattle. Ecosphere 2011, 2, 17. [CrossRef]

66. Garcia-Carmona, M.; Arcenegui, V.; Garcia-Orenes, F.; Mataix-Solera, J. The role of mosses in soil stability, fertility and microbiology six years after a post-fire salvage logging management. J. Environ. Manage. 2020, 262, 110287. [CrossRef] [PubMed]

67. Miller, R.F.; Ratchford, J.; Roundy, B.A.; Tausch, R.J.; Hulet, A.; Chambers, J. Response of Conifer-Encroached Shrublands in the Great Basin to Prescribed Fire and Mechanical Treatments. Rangel. Ecol. Manag. 2014, 67, 468-481. [CrossRef]

68. Johansen, J.R.; Stclair, L.L.; Webb, B.L.; Nebeker, G.T. Recovery patterns of cryptogamic soil crusts in desert rangelands following fire disturbance. Bryologist 1984, 87, 238-243. [CrossRef]

69. Condon, L.A.; Pyke, D.A. Resiliency of biological soil crusts and vascular plants varies among morphogroups with disturbance intensity. Plant Soil. 2018, 433, 271-287. [CrossRef]

70. Slate, M.L.; Durham, R.A.; Pearson, D.E. Strategies for restoring the structure and function of lichen-moss biocrust communities. Restor. Ecol. 2020, 28, S160-S167. [CrossRef]

71. Yarnell, R.W.; Scott, D.M.; Chimimba, C.T.; Metcalfe, D.J. Untangling the roles of fire, grazing and rainfall on small mammal communities in grassland ecosystems. Oecologia 2007, 154, 387-402. [CrossRef]

72. Panzer, R. Compatibility of prescribed burning with the conservation of insects in small, isolated prairie reserves. Conserv. Biol. 2002, 16, 1296-1307. [CrossRef]

73. Coppedge, B.R.; Fuhlendorf, S.D.; Harrell, W.C.; Engle, D.M. Avian community response to vegetation and structural features in grasslands managed with fire and grazing. Biol. Conserv. 2008, 141, 1196-1203. [CrossRef]

74. Hovick, T.J.; Elmore, R.D.; Fuhlendorf, S.D.; Engle, D.M.; Hamilton, R.G. Spatial heterogeneity increases diversity and stability in grassland bird communities. Ecol. Appl. 2015, 25, 662-672. [CrossRef] 
75. Davis, M.A.; Peterson, D.W.; Reich, P.B.; Crozier, M.; Query, T.; Mitchell, E.; Huntington, J.; Bazakas, P. Restoring savanna using fire: Impact on the breeding bird community. Restor. Ecol. 2000, 8, 30-40. [CrossRef]

76. Joern, A.; Laws, A.N. Ecological Mechanisms Underlying Arthropod Species Diversity in Grasslands. Annu. Rev. Entomol. 2013, 58, 19. [CrossRef]

77. Chiarani, E.; Bettio, M.; Fontana, C.S. Temporal changes in bird communities in areas with different histories of fire disturbance in highland grasslands of Brazil. PLoS ONE 2020, 15, 18. [CrossRef]

78. Betancourt, J.L. Energy flow and the "grassification" of desert shrublands. Proc. Natl. Acad. Sci. USA 2015, 112, 9504-9505. [CrossRef]

79. Mulqueeny, C.M.; Goodman, P.S.; O'Connor, T.G. Landscape-level differences in fire regime between block and patch-mosaic burning strategies in Mkuzi Game Reserve, South Africa. Afr. J. Range. For. Sci. 2010, 27, 143-150. [CrossRef]

80. Van der Werf, G.R.; Randerson, J.T.; Giglio, L.; Leeuwen, T.T.v.; Chen, Y.; Rogers, B.M.; Mu, M.; Van Marle, M.J.; Morton, D.C.; Collatz, G.J. Global fire emissions estimates during 1997-2016. Earth Syst. Sci. Data. 2017, 9, 697-720. [CrossRef]

81. Munoz-Rojas, M.; Erickson, T.E.; Martini, D.; Dixon, K.W.; Merritt, D.J. Soil physicochemical and microbiological indicators of short, medium and long term post-fire recovery in semi-arid ecosystems. Ecol. Indic. 2016, 63, 14-22. [CrossRef]

82. Pellegrini, A.F.; Hoffmann, W.A.; Franco, A.C. Carbon accumulation and nitrogen pool recovery during transitions from savanna to forest in central Brazil. Ecology 2014, 95, 342-352. [CrossRef]

83. Romanyà, J.; Casals, P.; Vallejo, V.R. Short-term effects of fire on soil nitrogen availability in Mediterranean grasslands and shrublands growing in old fields. For. Ecol. Manag. 2001, 147, 39-53. [CrossRef]

84. Blank, R.R.; Allen, F.L.; Young, J.A. Influence of simulated burning of soil-litter from low sagebrush, squirreltail, cheatgrass, and medusahead on water-soluble anions and cations. Int. J. Wildland Fire 1996, 6, 137-143. [CrossRef]

85. Stubbs, M.M.; Pyke, D.A. Available nitrogen: A time-based study of manipulated resource islands. Plant Soil. 2005, $270,123-133$. [CrossRef]

86. Perry, L.G.; Blumenthal, D.M.; Monaco, T.A.; Paschke, M.W.; Redente, E.F. Immobilizing nitrogen to control plant invasion. Oecologia 2010, 163, 13-24. [CrossRef]

87. Pellegrini, A.F.A.; Ahlstrom, A.; Hobbie, S.E.; Reich, P.B.; Nieradzik, L.P.; Staver, A.C.; Scharenbroch, B.C.; Jumpponen, A.; Anderegg, W.R.L.; Randerson, J.T.; et al. Fire frequency drives decadal changes in soil carbon and nitrogen and ecosystem productivity. Nature 2018, 553, 194-198. [CrossRef] [PubMed]

88. Suding, K.N. A leak in the loop. Nature 2013, 503, 472-473. [CrossRef] [PubMed]

89. Wan, S.Q.; Hui, D.F.; Luo, Y.Q. Fire effects on nitrogen pools and dynamics in terrestrial ecosystems: A meta-analysis. Ecol. Appl. 2001, 11, 1349-1365. [CrossRef]

90. Allen, C.R.; Gunderson, L.; Johnson, A.R. The use of discontinuities and functional groups to assess relative resilience in complex systems. Ecosystems 2005, 8, 958-966. [CrossRef]

91. Davies, G.M.; Bakker, J.D.; Dettweiler-Robinson, E.; Dunwiddie, P.W.; Hall, S.A.; Downs, J.; Evans, J. Trajectories of change in sagebrush steppe vegetation communities in relation to multiple wildfires. Ecol. Appl. 2012, 22, 1562-1577. [CrossRef]

92. Bestelmeyer, B.T.; Tugel, A.J.; Peacock Jr, G.L.; Robinett, D.G.; Shaver, P.L.; Brown, J.R.; Herrick, J.E.; Sanchez, H.; Havstad, K.M. State-and-transition models for heterogeneous landscapes: A strategy for development and application. Rangel. Ecol. Manag. 2009, 62, 1-15. [CrossRef]

93. Wilson, A.M.; Latimer, A.M.; Silander, J.A. Climatic controls on ecosystem resilience: Postfire regeneration in the Cape Floristic Region of South Africa. Proc. Natl. Acad. Sci. USA 2015, 112, 9058-9063. [CrossRef]

94. Feurdean, A.; Ruprecht, E.; Molnar, Z.; Hutchinson, S.M.; Hickler, T. Biodiversity-rich European grasslands: Ancient, forgotten ecosystems. Biol. Conserv. 2018, 228, 224-232. [CrossRef]

95. Strömberg, C.A.E. Evolution of grasses and grassland ecosystems. Annu. Rev. Earth. Planet. Sci. 2011, 39, 517-544. [CrossRef]

96. Bond, W.J.; Keeley, J.E. Fire as a global 'herbivore': The ecology and evolution of flammable ecosystems. Trends Ecol. Evol. 2005, 20, 387-394. [CrossRef] [PubMed]

97. Feurdean, A.; Marinova, E.; Nielsen, A.B.; Liakka, J.; Veres, D.; Hutchinson, S.M.; Braun, M.; Timar-Gabor, A.; Astalos, C.; Mosburgger, V. Origin of the forest steppe and exceptional grassland diversity in Transylvania (central-eastern Europe). J. Biogeogr. 2015, 42, 951-963. [CrossRef]

98. Bond, W.J.; Midgley, G.F.; Woodward, F.I. The importance of low atmospheric $\mathrm{CO}_{2}$ and fire in promoting the spread of grasslands and savannas. Glob. Chang. Biol. 2003, 9, 973-982. [CrossRef] 